\title{
Quality parameters of fermented kvass extract
}

\author{
I. Lidums, D. Karklina, A. Kirse \\ Faculty of Food Technology, Latvia University of Agriculture, \\ Liela Str. 2, Jelgava, LV-3001, Latvia \\ E-mail:ivo@ilm.lv
}

cross $^{\text {ref }}$ http://dx.doi.org/10.5755/j01.ct.67.1.15828

Received 14 May 2015; Accepted 6 June 2016

\begin{abstract}
The aim of this research was to compare the commercially available kvass concentrate to the kvass extract which was experimentally produced from the naturally fermented kvass. Dry matter was determined according to the standard ISO 2173:2003, active acidity - ISO 10523:2012, and apparent viscosity was measured with a DV-III Ultra Brookfield rheometer, using a spindle SC4-18 with the speed $50 \mathrm{rpm}$ at $26.9^{\circ} \mathrm{C}$. Sugars were determined using high-performance liquid chromatography. The sensory evaluation of kvass drinks (recombined kvass concentrate and extract) was performed according to the ISO 4121:2003. The dry matter content in the kvass concentrate (Ltd. Ilgzeem) was $69 \%$; it was diluted with distilled water to the dry matter content $32.4 \pm 0.2 \%$ of kvass extract (made from Ltd. Liepzeme kvass). Active acidity in the kvass concentrate was significantly $(p=0.012)$ lower $(p H 2.86)$ than in the kvass extract ( $p H 4.18)$. Apparent viscosity in the kvass extract was $13.68 \mathrm{mPa} \cdot \mathrm{s}$ and in the kvass concentrate $5.22 \mathrm{mPa} \cdot \mathrm{s}$. Major sugars in the kvass extract were fructose and glucose and in the commercial kvass concentrate - fructose. Hedonic evaluation showed that there were no significant differences $(p>0.05)$ in the preference of kvass drinks. The intensity of aroma, flavour and acidity was significantly more pronounced in the kvass drink made from the commercial kvass concentrate.
\end{abstract}

Key words: kvass extract, evaporation, kvass drink, sensory evaluation.

\section{Introduction}

Kvass (spelled also as kvass) is a traditional beverage in East Europe, typically produced from rye or dried rye bread by natural fermentation [1]. Kvass has been very popular in Russia and the former Soviet Union; its consumption has increased due to massive advertising, stressing its benefits for health. Kvass is usually sold unfiltered and contains yeast; therefore, the alcohol content is difficult to standardize. Usually, kvass contains not more than $1.5 \%$ of alcohol by volume, but if it stands for a longer time, the concentration may become $2.5 \%$ or higher. Unlike beer, kvass is generally considered to be a non-alcoholic beverage and is drunk by children of all ages without any limit [2].

Naturally fermented kvass has a short shelf-life which does not allow manufacturers to expand the trade in further regions. One of the most promising methods of producing kvass is fermented kvass made from the kvass wort concentrate/extract [3, 4]. Kvass extracts have a longer shelf-life, they are substantially free of ethanol and could be used by general use consumers who abstain from alcohol for various reasons. Kvass extracts can be diluted with still or carbonated water to produce drinks at a desired water-to-kvass-extract proportion (the taste could be mild or stronger). In the Russian patent, the kvass concentrate production method is described. Fermented kvass wort (enzymes are used during mashing) is sterilized and concentrated to the dry matter content of 10-25\%. The concentration is completed with a vacuum evaporator, and the alcohol content is not higher than 1 vol.\%. Organic acids and volatile compounds are not lost in the evaporation process, and the shelf-life of this concentrate is up to one year [5].

Kvass and kvass concentrate are widely consumed in Russia; therefore, the kvass concentrate quality parameters are defined in the GOST 28538-90 standard (Kvass wort concentrate, concentrates and extracts kvass) of the Russian Federation. Dry matter content in the kvass concentrate must be $70.0 \pm 2.0 \%$, the $p H$ value is not defined, but acidity must range from 16 to $40 \mathrm{~cm}^{3} 1 \mathrm{M}$ $\mathrm{NaOH}$ solution per $100 \mathrm{~g}$ concentrate $[3,6]$. The shelf-life of the kvass concentrate is at least 8 months [6]. The kvass concentrate may be stored up to 12 months at $-40{ }^{\circ} \mathrm{C}$ to $+30^{\circ} \mathrm{C}[3]$.

Kvass concentrates sold in Latvia are made from sugar, barley and rye malt extracts, drinking water and acidity regulators (citric or lactic acid). The aim of this research was to compare the commercially available kvass concentrate with the kvass extract which was experimentally produced from the naturally fermented kvass.

\section{Materials and methods}

\section{Experimental design}

Experiments were carried out at the Department of Food Technology, Latvia University of Agriculture, from February to April 2015. The object of the research was kvass concentrates-extracts. The commercially available Ltd. Ilgzeem kvass concentrate was compared with the kvass extract made from Ltd. Liepzeme naturally fermented non-pasteurised, non-filtered bread kvass. 


\section{Kvass extract production}

Carbon dioxide content was reduced Ltd. Liepzeme kvass using Magnetic stirrer MSH 300 for $15 \mathrm{~min}$ to reduce foaming during vacuum evaporation. The kvass extract was produced using a rotary vacuum evaporator Heidolph Laborata 4000 efficient in two stages. The parameters of the extraction method were the temperature of $50{ }^{\circ} \mathrm{C}$ of the whole extraction process, $30 \mathrm{rpm}$ for the first $30 \mathrm{~min}$, and from 50 to $60 \mathrm{rpm}$ for over an hour.

\section{Kvass concentrate and extract analysis}

Dry matter content was determined with a digital refractometer DR301-95 according to the ISO 2173:2003 standard.

Active acidity was determined in accordance with the ISO 10523:2012 standard.

Apparent viscosity was measured with a DV-III Ultra Rheometer (Brookfield Engineering Laboratories, Inc., USA) using a spindle SC4-18 with the speed of $50 \mathrm{rpm}$ at $26.9^{\circ} \mathrm{C}$.

Sugar content (fructose, glucose, sucrose, and maltose) was determined using the high-performance liquid chromatography (HPLC) method (Shimadzu LC 20 Prominence) [7]. The method is based on the chromatographic separation of sugars and their retention time. The identification of sugars in the kvass concentrate and extract was done by comparing retention times of individual sugars in the reference vs. the tested solution (qualitative analysis). The determination parameters were as follows: detector - a refractive index detector RID-10A; column - Alltech NH2 (4.6 mm × $250 \mathrm{~mm} \times 5 \mu \mathrm{m})$; temperature $+30{ }^{\circ} \mathrm{C}$; isocratic elution regime; mobile phase: A - acetonitrile, B - deionized water (A70 : B30); the capacity of the injection sample - $10 \mu \mathrm{l}$; total time of analysis - up to $20 \mathrm{~min}$; the rate of slow $-1.00 \mathrm{ml} / \mathrm{min}$.

Sensory evaluation of the kvass concentrate and kvass extract was performed according to the ISO 4121:2003. The kvass concentrate was diluted with distilled water to the dry matter content of the kvass extract. Kvass drinks were made from the kvass concentrate and extract with the equal dry matter content. $20 \mathrm{ml}$ of kvass concentrate or extract were diluted with $80 \mathrm{ml}$ of distilled water and carbonated. The hedonic scale was used to determine the overall preference of kvass drinks. The line scale was used to evaluate the intensity of sensory properties (aroma, flavour, acidity, and colour) of kvass drinks. Kvass samples were evaluated sensorily by 34 panellists (47\% men and $53 \%$ women, 18 panellists from Latvia and 16 panellists from Tajikistan), age 26-40 years.

\section{Data analysis}

The obtained data processing was performed with the statistical software R 3.0.2 and Microsoft Office Excel 14.0 for Windows; the mean values and standard deviations were calculated. The ANOVA and Tukey's test were used for data cross-comparison. For the interpretation of the results it was assumed that $\alpha=0.05$ with a $95 \%$ confidence.

\section{Results and discussion}

Dry matter content in the commercial kvass concentrate (Ltd. Ilgzeem) was $69 \%$, therefore it was diluted with distilled water to the dry matter content 32.4 $\pm 0.2 \%$ of kvass extract (made from Ltd. Liepzeme kvass) so that the obtained results could be comparable. In laboratory conditions, it was not possible to obtain a kvass extract with dry matter $>35 \%$.

The active acidity in the kvass concentrate was significantly $(p=0.012)$ lower $(p H 2.86)$ than in the kvass extract $(p H 4.18)$. The commercial kvass concentrate contains an acidity regulator - the lactic acid, and this could explain the lower $p H$ (higher acidity). The $p H$ of bottled fermented kvass (Ltd. Liepzeme) ranges from 3.77 to 3.88 in storage [8].

Apparent viscosity in the kvass extract was $13.68 \pm 0.08 \mathrm{mPa} \cdot \mathrm{s}$ and $5.22 \pm 0.05 \mathrm{mPa} \cdot \mathrm{s}$ in the kvass concentrate. Since the next step of the kvass extract research will be kvass extract powder, apparent viscosity is an important parameter in order to choose the most suitable concentration and the drying method.

The major sugars in the kvass extract were fructose and glucose and in the commercial kvass concentrate fructose (Table 1). Total sugar content was not significantly different in the kvass extract and the concentrate $(p=0.189)$.

Table 1. Sugar content in kvass extract and concentrate

\begin{tabular}{|c|c|c|}
\hline Sugars, g/l & Kvass extract & Kvass concentrate \\
\hline Fructose & $92.20 \pm 0.89$ & $163.80 \pm 1.61$ \\
\hline Glucose & $77.60 \pm 0.65$ & $35.60 \pm 0.31$ \\
\hline Sucrose & $29.52 \pm 0.23$ & 0 \\
\hline Maltose & $7.97 \pm 0.07$ & $9.87 \pm 0.03$ \\
\hline Total & $207.29 \pm 1.84$ & $209.27 \pm 1.95$ \\
\hline
\end{tabular}

The commercial kvass concentrate does not contain any sucrose; however, sugar is the main ingredient. During the kvass concentrate production, sucrose hydrolysis might occur in acidic conditions (lactic acid in this case), forming a mixture of glucose and fructose [9].

Dry matter content for kvass drinks made for sensory evaluation was $6.0 \pm 0.1 \%$. Two samples were prepared: sample A (Ltd. Liepzeme kvass extract) and sample B (made from Ltd. Ilgzeem kvass concentrate). The samples were evaluated by panellists from Latvia and Tajikistan.

The results of hedonic evaluation showed that there were no significant differences $(p>0.05)$ in the average preference of kvass drinks (Fig. 1). Panellists from Latvia and Tajikistan showed significantly different preferences of the kvass drink. 


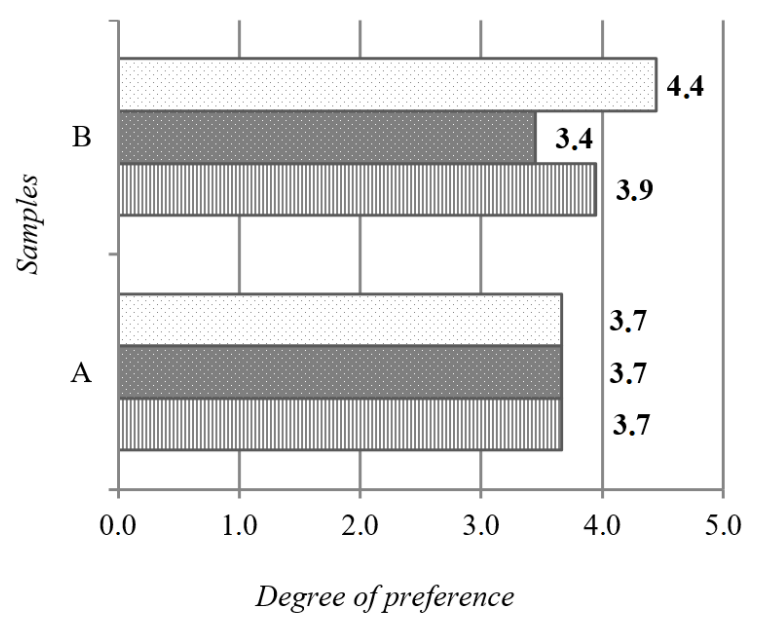

$\square$ Tajikistani panellists $\quad$ Latvian panellists $\quad$ mTotal

Fig. 1. Results of hedonic evaluation of kvass drinks.

Tajikistani panellists preferred sample B over sample A $(p=0.013)$, while Latvian panellists liked sample A more $(p=0.038)$.

The intensity of all sensory properties (aroma, flavour, and acidity) except colour was significantly more pronounced in the kvass drink sample B $(p=0.012)$. Colour intensity was similar in both kvass drinks $(p>0.05)$ (Fig. 2).

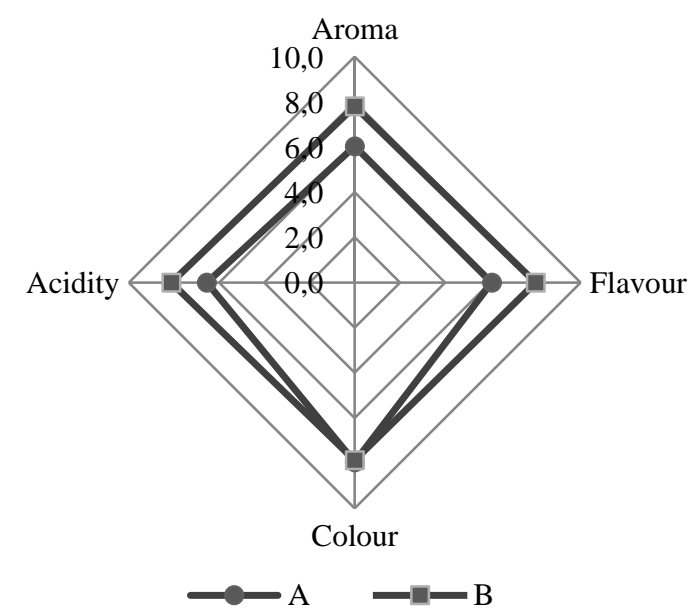

Fig. 2. The intensity of sensory properties of kvass drinks.

The evaporation of water and aroma volatiles during the kvass extraction process (in order to obtain the kvass extract) could explain the lower aroma intensity in sample A. The more intense acidity in sample B was due to the acidity regulator citric acid, which is an ingredient in the commercial kvass concentrate. One of the possibilities to obtain a more robust flavour and aroma in sample A could be the lower water-to-kvass extract ratio in the kvass drink, i. e. a higher dry matter content (up to $10 \%$ ).

\section{Conclusions}

1. Dry matter content in the experimental kvass extract was $32.4 \pm 0.2 \%$ (made from the Ltd. Liepzeme kvass). Active acidity in the kvass concentrate was significantly $(p=0.012)$ lower $(p H 2.86)$ than in the kvass extract ( $p H 4.18)$. Major sugars in the kvass extract were fructose and glucose, and in the commercial kvass concentrate it was fructose.

2. Apparent viscosity in the kvass extract was $13.68 \mathrm{mPa} \cdot \mathrm{s}$ and in kvass concentrate $5.22 \mathrm{mPa} \cdot \mathrm{s}$.

3. Hedonic evaluation showed that there were no significant differences $(p>0.05)$ in the preference of kvass drinks. The intensity of aroma, flavour and acidity was significantly more pronounced in the kvass drink made from the commercial kvass concentrate.

\section{References}

1. Сергеева И. Ю., Унщикова Т. А., Рысина В. Ю. Направления совершенствования технологии кваса брожения на основе анализа современных научнотехнических разработок // Техника и технология пищевых производств. 2014. Vol. 34. N 3. P. 69-78.

2. Jargin S. V. Kvass: A possible contributor to chronic alcoholism in the former Soviet Union-Alcohol content should be indicated on labels and in advertising // Alcohol and Alcoholism. 2009. Vol. 44. N 5. P. 529. http://dx.doi.org/10.1093/alcalc/agp055

3. Исаева В. С., Иванова Т. В., Степанова Н. М., Думбрава Л. М., Раттэль Н. Н. Современные аспекты производства кваса (теория, исследования, практика). Москва, Профессия, 2009. 304 с.

4. Шабанова Т. А., Егорова А. Е. Концентрат кваса брожения «Аграфенушка»// Пиво и напитки. 2009. Vol. 3. P. 26-28.

5. Тихонова Т. А., Тихонов В. Б., Кобелев К. В. Пат. 2447141 Российская Федерация МПК С12G3/02, 2012.

6. Помозова В. А. Производство кваса и безалкогольных напитков: учебное пособие. Санкт-Петербург, ГИОДР, 2006. $192 \mathrm{c}$.

7. Priecina L., Karklina D. Determination of major sugars in fresh and dried spices and vegetables using high performance liquid chromatography // Conference proceedings of 9th Baltic Conference on Food Science and Technology FOODBALT 2014. Jelgava, 2014. P. 198201.

8. Lidums I., Karklina D., Kirse A. Quality changes of naturally fermented kvass during production stages // Conference proceedings of 9th Baltic Conference on Food Science and Technology FOODBALT 2014. Jelgava, 2014. P. 188-191.

9. Brighenti D. M., Carvalho C. F., Brighenti C. R. G., Carvalho S. M. Inversion of the sucrose using citric acid and lemon juice for preparing energetic diet of Apis mellifera Linnaeus, 1758 // Ciência e Agrotecnologia. 2011. Vol. 35. N 2. P. 297-304. http://dx.doi.org/10.1590/S1413-70542011000200010 


\section{FERMENTUOTOS GIROS EKSTRAKTO KOKYBĖS}

\section{PARAMETRAI}

\section{S a n t r a u k a}

Šio darbo tikslas - palyginti komercini giros koncentratą su eksperimentiniu būdu iš natūraliai fermentuotos giros gautu ekstraktu.

Sausų medžiagų kiekis ir aktyvusis rūgštingumas nustatyti remiantis ISO standartais, klampa išmatuota DV-III Ultra Brookfield reometru. Cukrų kiekis nustatytas taikant didelès raiškos skysčių chromotografijos metodą.

Nustatyta, kad sausų medžiagų kiekis UAB ,Ilgzeem“ giros koncentrate buvo $69 \%$. Sis koncentratas praskiestas distiliuotoju vandeniu iki 32,4 $\pm 0,2 \%$ sausujų medžiagų kiekio, kad jị būtų galima palyginti su UAB „Liepzeme“ natūralios fermentacijos tokios koncentracijos gaminamu giros ekstraktu (laboratorinemis sąlygomis neįmanoma gauti didesnès kaip $35 \%$ koncentracijos ekstrakto).

Nustatyta, kad giros koncentrato aktyvusis rūgštingumas buvo gerokai $(p=0,012)$ mažesnis $(p H 2,86)$ negu giros ekstrakto (pH 4,18). Pastarojo klampa sieke 13,68 $\mathrm{mPa} \cdot \mathrm{s}$, o giros koncentrato klampa buvo $5,22 \mathrm{mPa} \cdot \mathrm{s}$. Giros ekstrakte daugiausia buvo fruktozès ir gliukozès, o komerciniame koncentrate vyravo fruktozè. Poveikio vertinimo (arba hedonistinis) tyrimas parodè, kad tarp šių abiejų giros gèrimų nèra didelio skirtumo, tačiau giros, gautos iš komercinio koncentrato, aromatas, skonis ir rūgštingumas yra gerokai ryškesnis. 